Editorial

\title{
Sustainable Real Estate: Management, Assessment and Innovations
}

\author{
Pierfrancesco De Paola ${ }^{1}\left[\right.$, Francesco Tajani ${ }^{2, *}$ (i) and Marco Locurcio ${ }^{3}[(])$ \\ 1 Department of Industrial Engineering, University of Naples "Federico II", 80125 Napoli, Italy; \\ pierfrancesco.depaola@unina.it \\ 2 Department of Architecture and Design, Sapienza University of Rome, 00196 Roma, Italy \\ 3 Department of Civil, Environmental, Land, Building Engineering and Chemistry, \\ Polytechnic University of Bari, 70126 Bari, Italy; marco.locurcio@poliba.it \\ * Correspondence: francesco.tajani@uniroma1.it
}

check for updates

Citation: De Paola, P.; Tajani, F.; Locurcio, M. Sustainable Real Estate: Management, Assessment and Innovations. Sustainability 2021, 13, 4676. https://doi.org/10.3390/ su13094676

Received: 14 April 2021

Accepted: 20 April 2021

Published: 22 April 2021

Publisher's Note: MDPI stays neutral with regard to jurisdictional claims in published maps and institutional affiliations.

Copyright: (c) 2021 by the authors. Licensee MDPI, Basel, Switzerland. This article is an open access article distributed under the terms and conditions of the Creative Commons Attribution (CC BY) license (https:// creativecommons.org/licenses/by/ $4.0 /)$.

\section{Introduction}

Production and consumption activities have determined a weakness of the sustainable real estate economy. The main problems are the subordination of public decision-making, which is subjected to pressure from big companies, inefficient appraisal procedures, excessive use of financial leverage in investment projects, the atypical nature of markets, income positions in urban transformations and the financialization of real estate markets with widespread negative effects.

A delicate role in these complex problems is assigned to real estate appraisal activities, called to formulate value judgments on real estate goods and investment projects, the prices of which are often formed in atypical real estate markets, giving ever greater importance to sustainable development and transformation issues.

This Special Issue is dedicated, but not only limited, to developing and disseminating knowledge and innovations related to most recent real estate evaluation methodologies applied in the fields of architecture and civil, building, environmental and territorial engineering.

A total of 24 papers were submitted. Following a rigorous procedure of peer review, only 12 papers were accepted and published. The different countries of the Authors' affiliation (Korea, Lithuania, Italy, UK, Finland, Poland and so on) have given the Special Issue a strongly international character.

Considering all 24 papers submitted, 19 different countries of the Authors' affiliation can be found (Figure 1). This number drops to 15 if only the published papers are contemplated (Figure 2).

In compliance with the objectives of this Special Issue, the published papers can be grouped into three main themes, reflecting the major lines of research within the real estate sector: (i) sustainable real estate (five papers), (ii) econometric models (five papers) and (iii) multi-criteria decision analysis (two papers). 


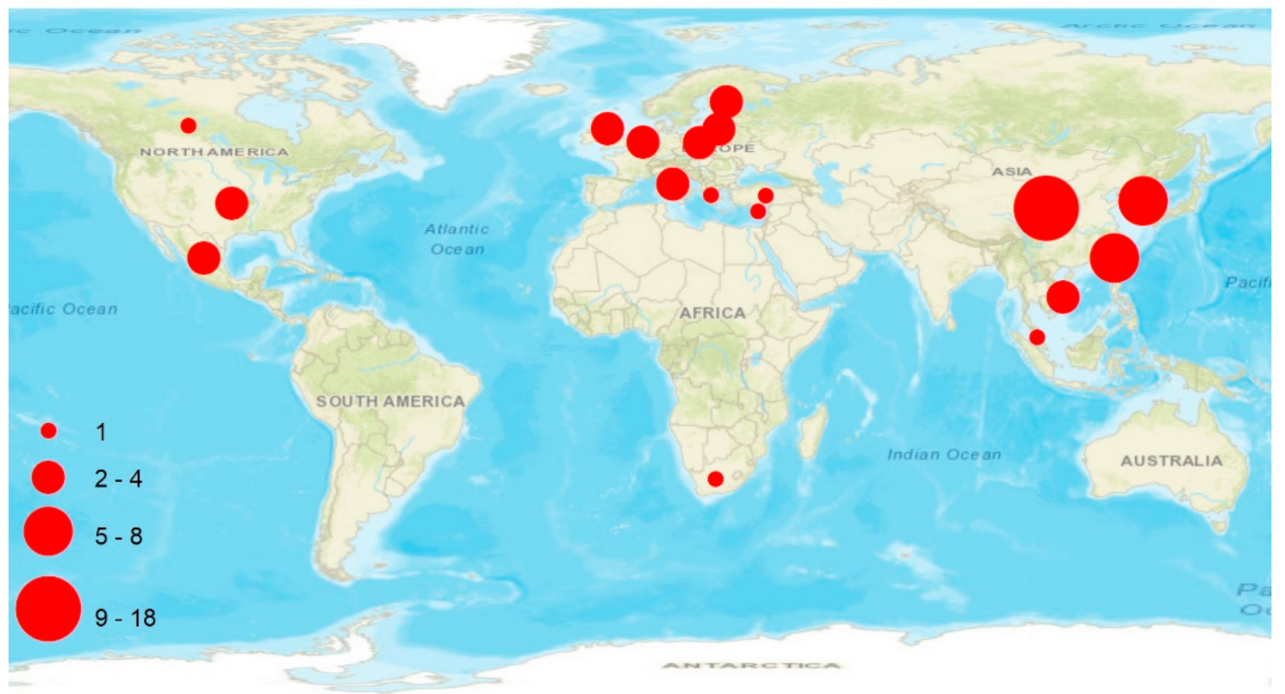

Figure 1. Number of Authors for countries affiliation (papers submitted).

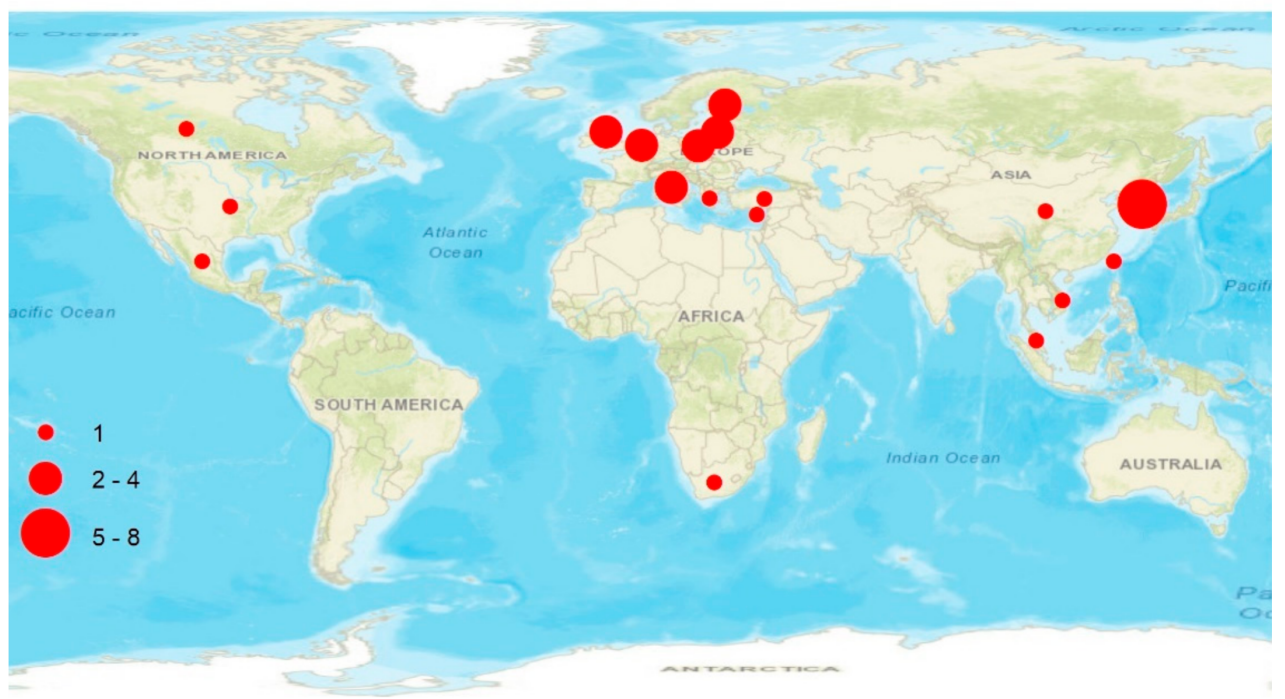

Figure 2. Number of Authors for countries affiliation (papers published).

\section{Sustainable Real Estate}

The theme of sustainability in real estate is central to this Special Issue, and it is declined in its environmental, social and economic components.

In "Pricing ESG Equity Ratings and Underlying Data in Listed Real Estate Securities" Dirk Brounen, Gianluca Marcato and Hans Op 't Veld [1] examine and discuss the application of transparent environmental, social and governance (ESG) ratings and their interaction with public real estate performance across European markets. The Authors, starting from the European Public Real Estate Association's (EPRA) Sustainability Best Practices Recommendations (sBPR) database for the listed European real estate market, construct two ESG measures that analyze the ESG completeness and performance. Through a statistical analysis on a sample of 64 European listed real estate firms, the Authors outline that since both ESG measures covary across firms, then firms that score highly on ESG completeness also tend to score higher than average on ESG performance.

In "The Unequal Impact of Natural Landscape Views on Housing Prices: Applying Visual Perception Model and Quantile Regression to Apartments in Seoul", Hyejin Lee, Byoungkil Lee and Sangkyeong Lee [2] analyze the impact of natural landscape views on housing prices for apartments in Seoul. Through a visual perception GIS-based model, the Authors 
describe the natural landscape views of Seoul and the corresponding impact on housing prices. The implementation of a quantile regression (that takes into account housing factors as the net surface, the floor level, the location, etc.) highlights that natural landscape views have positive impacts on housing prices, in particular for higher-priced apartments.

The paper by Eerika Janhunen, Niina Leskinen and Seppo Junnila entitled "The Economic Viability of a Progressive Smart Building System with Power Storage" [3] sets out to understand the cash flows and economic viability of a real-life smart system investment in a building. The "case building" is a European shopping center located in southern Finland involved in a smart energy investment (PV system, battery storage, active LEDs, EV charging, advanced demand management) equal to six million Euro in 2018. On February 2020, after the first full operational year of the smart energy system, the Authors have carried out a survey of six representatives of the case building's owner (three real estate managers, the business the development director and the CEO) in order to determine the smart readiness indicator (SRI), and are able to evaluate a building's potential to optimize the overall energy consumption. The case building's final score is $92 \%$ of the maximum on the SRI rating scale, which indicates that the building is indeed exceptionally smart in terms of its technological implementations. Furthermore, the performance indicators (IRR, ROI, NPV, payback period) show that the investment is also financially convenient.

The paper by Youngme Seo entitled "Varying Effects of Urban Tree Canopies on Residential Property Values across Neighborhoods, social and economic benefits" [4] utilizes spatial models to empirically evaluate the impact of Urban Tree Canopy (UTC) on residential property values in the housing market. The Author elaborates a dataset that includes 24,203 singlefamily residential sales from 2007 to 2015 in the city of Des Moines (Iowa). The dataset involves structural factors, such as the size of the living area, the size of land, bedrooms, bathrooms, construction year, condition of the structure, and presence and type of garage. Through a GIS-based model and buffering techniques the main "amenities" (accessibility and view) and "disamenities" (noise and traffic) are mapped. The application of MultiLevel Mixed (MLM) models points out that UTC determines a positive effect on housing prices, especially on those ones characterized by large sizes and located in more stately neighborhoods. In fact, trees and green surfaces are relevant not only for mitigating the environmental problems in the urban areas and reducing energy use, but they "shield" residential areas from the noise pollution generated by car traffic.

In "Do Women Affect the Final Decision on the Housing Market? A Case Study", Sabina Zróbek, Elzbieta Zysk, Mirosław Bełej and Natalija Lepkova [5] show the results of their research on the effect of customer gender on tenure choice (ownership or tenancy) in the housing market. The survey is conducted among residents of two cities-Olsztyn (Poland) and Vilnius (Lithuania). Through almost 200 questionnaires submitted from October to December 2019 to a specialized online platform, it has been possible to detect that women generally have greater decision-making autonomy in residential issues than men, with Lithuanian women doing this much more often than Polish women. Although the number of respondents' answers is not very large, the results may also contribute to more sustainable development of enterprises in the housing construction sector.

\section{Econometric Models}

Due to the dissemination of databases that combine real estate and socio-economic information, econometric models are widely used for forecasting issues in complex contexts where real estate takes on a central role.

In "The Impact of Uncertainty on State-Level Housing Markets of the United States: The Role of Social Cohesion" Linyan Dai and Xin Sheng [6] study the impact of uncertainty on housing markets across the 50 states of the USA, plus the District of Columbia, using the local projection method for panel data. The application of a series of indexes (index values of the Freddie Mac House Price Indexes, adjusted Consumer Price Index, State Social Capital Index, Macro and Financial Uncertainty Indexes), constructed at a monthly frequency and ranging from December 1999 to December 2019, highlights that macroeconomic and 
financial uncertainties reduce real housing returns, with the strongest effect originated from the macro-economic uncertainty over the long term.

The paper by Yener Coskun, Christos Bouras, Rangan Gupta and Mark E. Wohar entitled "Multi-Horizon Financial and Housing Wealth Effects across the U.S. States" [7] uses an expanded dataset (period 1975-2012) with regional data to investigate the link between wealth and consumption in the USA. The goal is to better understand the wealth effectinduced household consumption behaviors in the USA and the role of housing and financial wealth effects. Through the multi-horizon test the Authors outline that generally in the USA housing (financial) wealth growth causes consumption growth.

In "Retirement Age and Housing Consumption: The Case of South Korea" Chunil Kim, Hyobi Choi and Yeol Choi [8] investigate the impact of the timing of retirement on housing consumption. The Authors observe that in the "aged societies" there are many people who do not save enough money in preparation for retirement, and they are thus not likely to have the essential financial resources required to maintain their standard of living in retirement. In these cases, for which the house is often the largest asset owned by most households, Housing Downsizing is a possible strategy that ensures a good standard of living of the owners. Thanks to a dataset containing socio-demographic and financial information for households of all generations, through a statistical treatment, the Authors analyze the demand for housing by comprehensively considering the simultaneous linkage of housing tenure choice and housing consumption using.

The paper by Kuo-Cheng Hsu entitled "House Prices in the Peripheries of Mass Rapid Transit Stations Using the Contingent Valuation Method" [9] aims to examine the residential market of the areas where the mass rapid transit (MRT) stations in the Taipei metropolitan area in Taiwan are located. To assess the prices that people are willing to pay for houses in the peripheries of MRT stations, the Author has submitted a willingness-to-pay questionnaire and has analyzed the outputs using the contingent valuation method. Furthermore, a Tobit regression model points out that, regardless of the typology of transit stations (elevated or underground stations), the current market house prices are higher than the price levels the respondents were willing to pay.

The paper by Marco Locurcio, Pierluigi Morano, Francesco Tajani and Felicia Di Liddo entitled "An Innovative GIS-Based Territorial Information Tool for the Evaluation of Corporate Properties: An Application to the Italian Context" [10] proposes an Automated Valuation Model for the corporate market segment, in order to support the investors', the credit institutions' and the public entities' decision processes. The application of the model to the corporate real estate segment market of the cities of Rome and Milan (Italy) outlines the potentialities of this approach in property big data management. The elaboration of input and output data in the GIS environment allows the development of an intuitive platform for the immediate representation of the results and their easy interpretation, even to non-expert users.

\section{Multi-Criteria Decision Analysis (MCDA)}

MCDAs remain particularly useful tools in uncertain decision-making contexts in which different stakeholders intervene, often with conflicting objectives, and the decisionmaker is called to choose through a shared platform.

The paper by Eglè Klumbytè, Raimondas Bliūdžius, Milena Medineckienė and Paris A. Fokaides entitled "An MCDM Model for Sustainable Decision-Making in Municipal Residential Buildings Facilities Management" [11] presents a multi-criteria decision-making (MCDM) model for the sustainable decision-making, tailored to municipal residential buildings facilities management. The delivered model is applied to 20 municipal social housing buildings of Kaunas city, located in Lithuania, to identify the worst-case real estate, for which strategic decisions have to be made. The proposed model starts from 109 requirements of three groups for social housing buildings: through expert assessment methods, the Authors reduce the requirements to 30 (10 normative, 10 municipal and 10 resident requirements). The main outcomes of the model concern recommendations for the management, use and 
disposal of municipal buildings, in compliance with the principles of public law, rationality, management efficiency and economic benefits.

In "An Integrated Methodological Analysis for the Highest Best Use of Big Data-Based Real Estate Development", Jaehwan Kim, Ducksu Seo and You Seok Chung [12] investigate the integration of methods for real estate development planning and feasibility studies in the changing business environments of emerging big data. Through the support of a valuer of the Korea Land and Housing Corporation, the study used big data to distinguish those factors preferred by business entities planning to implement high-rise building mixeduse development projects, and by consumers who look at such projects, to determine evaluation items. The effects of high-rise mixed-use building development projects are analyzed through four categories (economy and industry, society and culture, technology and environment, reputation) divided into 13 evaluation fields and 39 evaluation factors. The fuzzy inference is used to measure the influence factors of each category and the Analytic Hierarchy Process (AHP) technique is implemented to set priorities based on the factors in each hierarchy. The methodological approach uses different techniques (AHP and fuzzy logic) combined with big data for the definition of the highest and best use of high-rise mixed-use buildings.

\section{Concluding Remarks}

The sector of construction and real estate in general has taken on a central role with regard to the theme of environmental sustainability, declined from different points of view, such as the need to limit land consumption through incentive mechanisms [13,14], the green enhancement of existing buildings [15-17] and/or parts of cities to be redeveloped [18]. Over the years, environmental sustainability has evolved to include social, financial and economic aspects [19-21]. Additionally, thanks to the spread of the 17 Sustainable Development Goals promoted by the United Nations Department of Economic and Social Affairs, the concept of sustainability has been expanding in recent years to environmental, social and governance (ESG) investments. ESG investments are key in the European Green Deal [22] and are constantly growing in the portfolio of investors around the world [23-25].

This Special Issue takes into account the several lines of current research developed in the field of "sustainable real estate". The 12 papers selected and published investigate different aspects (social, environmental, economic, etc.) of sustainability and the central role of real estate sector in achieving these objectives. Many papers, written by scholars and academics of prestigious universities and international research institutes, converge on the same topics, highlighting the interest and topicality of the proposed research issues and the relevance of real estate sector in achieving the objectives of sustainability.

Author Contributions: The paper is to be attributed in equal parts to all of the authors. All authors have read and agreed to the published version of the manuscript.

Funding: This research received no external funding.

Institutional Review Board Statement: Not applicable.

Informed Consent Statement: Not applicable.

Acknowledgments: The editors thank all the authors for their contributions.

Conflicts of Interest: The authors declare no conflict of interest.

\section{References}

1. Brounen, D.; Marcato, G.; Op't Veld, H. Pricing ESG Equity Ratings and Underlying Data in Listed Real Estate Securities. Sustainability 2021, 13, 2037. [CrossRef]

2. Lee, H.; Lee, B.; Lee, S. The Unequal Impact of Natural Landscape Views on Housing Prices: Applying Visual Perception Model and Quantile Regression to Apartments in Seoul. Sustainability 2020, 12, 8275. [CrossRef]

3. Janhunen, E.; Leskinen, N.; Junnila, S. The Economic Viability of a Progressive Smart Building System with Power Storage. Sustainability 2020, 12, 5998. [CrossRef] 
4. Seo, Y. Varying Effects of Urban Tree Canopies on Residential Property Values across Neighborhoods, social and economic benefits. Sustainability 2020, 12, 4331. [CrossRef]

5. Zróbek, S.; Zysk, E.; Bełej, M.; Lepkova, N. Do Women Affect the Final Decision on the Housing Market? A Case Study. Sustainability 2020, 12, 4652. [CrossRef]

6. Dai, L.; Sheng, X. The Impact of Uncertainty on State-Level Housing Markets of the United States: The Role of Social Cohesion. Sustainability 2021, 13, 3065. [CrossRef]

7. Coskun, Y.; Bouras, C.; Gupta, R.; Wohar, M.E. Multi-Horizon Financial and Housing Wealth Effects across the U.S. States. Sustainability 2021, 13, 1341. [CrossRef]

8. Kim, C.; Choi, H.; Choi, Y. Retirement Age and Housing Consumption: The Case of South Korea. Sustainability 2021, 13, 1286.

9. Hsu, K.C. House Prices in the Peripheries of Mass Rapid Transit Stations Using the Contingent Valuation Method. Sustainability 2020, 12, 8701. [CrossRef]

10. Locurcio, M.; Morano, P.; Tajani, F.; Di Liddo, F. An Innovative GIS-Based Territorial Information Tool for the Evaluation of Corporate Properties: An Application to the Italian Context. Sustainability 2020, 12, 5836. [CrossRef]

11. Klumbytè, E.; Bliūdžius, R.; Medineckienè, M.; Fokaides, P.A. An MCDM Model for Sustainable Decision-Making in Municipal Residential Buildings Facilities Management. Sustainability 2021, 13, 2820. [CrossRef]

12. Kim, J.; Seo, D.; Chung, Y.S. An Integrated Methodological Analysis for the Highest Best Use of Big Data-Based Real Estate Development. Sustainability 2020, 12, 1144. [CrossRef]

13. Balena, P.; Sannicandro, V.; Torre, C.M. Spatial analysis of soil consumption and as support to transfer development rights mechanisms. Lect. Notes Comput. Sci. 2013, 587-599. [CrossRef]

14. Morano, P.; Tajani, F.; Anelli, D. Urban planning decisions: An evaluation support model for natural soil surface saving policies and the enhancement of properties in disuse. Prop. Manag. 2020, 38, 699-723. [CrossRef]

15. Del Giudice, V.; Massimo, D.E.; De Paola, P.; Del Giudice, F.P.; Musolino, M. Green buildings for post carbon city: Determining market premium using spline smoothing semiparametric method. Smart Innov. Syst. Technol. 2021, 178, 1227-1236.

16. Del Giudice, V.; Massimo, D.E.; Salvo, F.; De Paola, P.; De Ruggiero, M.; Musolino, M. Market price premium for green buildings: A review of empirical evidence case study. Smart Innov. Syst. Technol. 2021, 178, 1237-1247.

17. Morano, P.; Locurcio, M.; Tajani, F. Energy production through roof-top wind turbines a GIS-based decision support model for planning investments in the city of Bari (Italy). Lect. Notes Comput. Sci. 2015, 9157, 104-119.

18. Morano, P.; Tajani, F.; Di Liddo, F.; Amoruso, P. The public role for the effectiveness of the territorial enhancement initiatives: A case study on the redevelopment of a building in disuse in an Italian small town. Buildings 2021, 11, 87. [CrossRef]

19. Tajani, F.; Morano, P. Evaluation of the economic sustainability of the projects in social housing. Lect. Notes Comput. Sci. 2014, 135-147. [CrossRef]

20. Tajani, F.; Morano, P.; Di Liddo, F.; Locurcio, M. An innovative interpretation of the DCFA evaluation criteria in the public-private partnership for the enhancement of the public property assets. Smart Innov. Syst. Technol. 2019, 100, 305-313.

21. Morano, P.; Tajani, F. The break-even analysis applied to urban renewal investments: A model to evaluate the share of social housing financially sustainable for private investors. Habit. Int. 2017, 59, 10-20. [CrossRef]

22. Communication from the Commission to the European Parliament, the European Council, the European Economic and Social Committee and the Committee of the Regions. The European Green Deal, Brussells 11.12.2019 COM(2019) 640 Final. Available online: https:/ / eur-lex.europa.eu/legal-content/EN/TXT/HTML/?uri=CELEX:52019DC0640\&from=EN (accessed on 13 April 2021).

23. US SIF Foundation. Report on US Sustainable and Impact Investing Trends 2020. Available online: https:/ /www.ussif.org/files / Trends\%20Report\%202020\%20Executive\%20Summary.pdf (accessed on 13 April 2021).

24. KPMG. Environmental, Social and Governance Report FY2020. Available online: https://assets.kpmg/content/dam/kpmg/cn/ pdf/en/2021/03/kpmg-china-environmental-social-and-governance-report-fy2020.pdf (accessed on 13 April 2021).

25. PWC. Environmental, Social and Governance (ESG) in Asia. Asset and Wealth Management 2020. Available online: https: //www.pwc.com/sg/en/asset-management/assets/environmental-social-and-governance-in-asia-awm.pdf (accessed on 13 April 2021). 